\section{Maternal Lineages of the Cultivated Strawberry, Fragaria $\times$ ananassa, Revealed by Chloroplast DNA Variation}

\author{
Masanori Honjo', Sono Kataoka, Susumu Yui, and Masami Morishita \\ National Agricultural Research Center for Tohoku Region, Nabeyashiki, 92 \\ Shimokuriyagawa, Morioka, Iwate 020-0123, Japan
}

Miyuki Kunihisa

National Institute of Vegetable and Tea Science, 3-1-1 Kannondai, Tsukuba, Ibaraki 305-8666, Japan

Takayoshi Yano, Megumi Hamano, and Hiromichi Yamazaki National Agricultural Research Center for Tohoku Region, Nabeyashiki, 92 Shimokuriyagawa, Morioka, Iwate 020-0123, Japan

Additional index words. Fragaria virginiana, Fragaria chiloensis, haplotype, maternal inheritance, maternal origin

Abstract. We analyzed sequence variation in chloroplast DNA (cpDNA) to investigate the origin of the cultivated strawberry, Fragaria $\times$ ananassa. From analysis of two noncoding regions, $t r n L-t r n F$ and $t r n R-r r n 5$, we found three haplotypes $(\mathrm{V}, \mathrm{C}$, and $\mathrm{X})$ in $F$. ×ananassa. Haplotype $\mathrm{V}$ corresponded to the haplotype of $F$. virginiana and was possessed by cultivars bred over a wide geographic range, including North America, Europe, and Japan. Almost all the North American cultivars analyzed in this study possessed haplotype $V$, suggesting a founder effect. Haplotype $C$ corresponded to the haplotype of $\boldsymbol{F}$. chiloensis and was detected mainly in Japanese cultivars. Haplotype $\mathrm{X}$ was found in only two English cultivars. This haplotype was positioned as intermediate between haplotypes $\mathrm{V}$ and $\mathrm{C}$ in a median-joining network and was considered to be representative of the process of differentiation between $F$. virginiana and $F$. chiloensis. Results of controlled crosses indicate that cpDNA haplotypes of $F$. Xananassa are maternally inherited. These results verify that $F$. ×ananassa is an interspecific hybrid between $F$. virginiana and $F$. chiloensis and indicate that traditional cultivars of $F$. $\times$ ananassa have been derived from at least three maternal lineages. We demonstrate that the cpDNA variation detected in this study can be used to verify parentage and for extending hypotheses about June yellows, a leaf variegation disorder in strawberry.

Determining the historical pedigree of cultivars is an important step in understanding the evolution of crop species (Matsuoka, 2005). It can also help to avoid inbreeding depression and to identify the origin of agronomically important traits.

The cultivated strawberry, Fragaria xananassa Duch., is one of the most economically important fruit crops in the world. It first arose from accidental hybridization between two American octoploid species, $F$. virginiana and $F$. chiloensis, in a European garden during the early to mid-1700s (Darrow, 1966). The number of $F$. chiloensis involved

\footnotetext{
Received for publication 19 June 2009. Accepted for publication 12 Aug. 2009.

We thank Naoe Suzuki for technical assistance; Rikiya Kimura, Setsuko Oki, Yukari Sakurai, and Keiko Iwabuchi for help in cultivation of plant materials; and anonymous reviewers for their valuable comments.

${ }^{1}$ To whom reprint requests should be addressed; e-mail amhonjo@affrc.go.jp.
}

in that first hybridization was claimed to have been only five plants, which were introduced from Chile to Europe in 1714 (Darrow, 1966). Systematic breeding began in England in the early 1800 s and in North America in the mid1800 s using a small number of native and cultivated clones (Darrow, 1966). Most modern strawberry cultivars are the progeny of this relatively narrow range of germplasm, although attempts have been made recently to increase genetic diversity by using wild genetic resources (Hancock et al., 2001; Luby et al., 2008). On the basis of pedigree data, Dale and Sjulin (1990) reported that the majority of modern North American cultivars came from only 17 cytoplasmic sources. However, further tracing was impossible owing to incomplete records.

Because chloroplast DNA (cpDNA) is unaffected by changes in ploidy, which can complicate phylogenetic analysis, the genome is particularly useful for the phylogenetic analysis of Fragaria. Potter et al. (2000) examined the sequence variation in cpDNA among 14 species of Fragaria with various
Table 1. Country of origin and the detected chloroplast DNA haplotype of 75 accessions of Fragaria ×ananassa and seven accessions of its wild relatives.

\begin{tabular}{|c|c|c|}
\hline Accessions & Country & Haplotype \\
\hline \multicolumn{3}{|c|}{ F. $\times$ ananassa cultivars in North America } \\
\hline Allstar & USA & V \\
\hline Arking & USA & $\mathrm{V}$ \\
\hline Blakemore & USA & $\mathrm{V}$ \\
\hline Cardinal & USA & $\mathrm{V}$ \\
\hline Chandler & USA & $\mathrm{V}$ \\
\hline Columbia & USA & $\mathrm{C}$ \\
\hline Donner & USA & $\mathrm{V}$ \\
\hline Douglas & USA & $\mathrm{V}$ \\
\hline Excelsior & USA & $\mathrm{V}$ \\
\hline Fairfax & USA & $\mathrm{V}$ \\
\hline Fresno & USA & $\mathrm{V}$ \\
\hline Geneva & USA & $\mathrm{V}$ \\
\hline Hecker & USA & $\mathrm{V}$ \\
\hline Holiday & USA & $\mathrm{V}$ \\
\hline Honeoye & USA & $\mathrm{V}$ \\
\hline Huxley & USA & $\mathrm{V}$ \\
\hline Lassen & USA & $\mathrm{V}$ \\
\hline Linn & USA & $\mathrm{V}$ \\
\hline Marshall & USA & $\mathrm{V}$ \\
\hline Missionary & USA & $\mathrm{V}$ \\
\hline Pajaro & USA & $\mathrm{V}$ \\
\hline Premier (Howard 17) & USA & $\mathrm{V}$ \\
\hline Raritan & USA & $\mathrm{V}$ \\
\hline Selva & USA & $\mathrm{V}$ \\
\hline Sequoia & USA & $\mathrm{V}$ \\
\hline Tioga & USA & $\mathrm{V}$ \\
\hline Tyee & Canada & $\mathrm{V}$ \\
\hline Vibrant & Canada & $\mathrm{V}$ \\
\hline Wiltguard & USA & $\mathrm{V}$ \\
\hline \multicolumn{3}{|c|}{ F. $\times$ ananassa cultivars in Europe } \\
\hline Cambridge Favourite & UK & $\mathrm{X}$ \\
\hline Cambridge Prizewinner & UK & $\mathrm{V}$ \\
\hline Deutch Evern & Germany & $\mathrm{V}$ \\
\hline Merton Princess & UK & $\mathrm{X}$ \\
\hline Oranda & Netherlands & $\mathrm{V}$ \\
\hline Redgauntlet & UK & $\mathrm{V}$ \\
\hline Senga Sengana & Germany & $\mathrm{V}$ \\
\hline \multicolumn{3}{|c|}{ F. $\times$ ananassa cultivars in Japan } \\
\hline Aiberry & Japan & $\mathrm{V}$ \\
\hline Akihime & Japan & $\mathrm{V}$ \\
\hline Asuka Wave & Japan & $\mathrm{C}$ \\
\hline Bellerouge & Japan & $\mathrm{V}$ \\
\hline Benihoppe & Japan & $\mathrm{V}$ \\
\hline Decorouge & Japan & $\mathrm{V}$ \\
\hline Enrai & Japan & $\mathrm{V}$ \\
\hline Everberry & Japan & $\mathrm{V}$ \\
\hline Fukuba & Japan & $\mathrm{C}$ \\
\hline Harunoka & Japan & $\mathrm{V}$ \\
\hline Haruyoi & Japan & $\mathrm{V}$ \\
\hline Hatsukuni & Japan & $\mathrm{C}$ \\
\hline Himiko & Japan & $\mathrm{C}$ \\
\hline Hokowase & Japan & V \\
\hline Kitanokagayaki & Japan & $\mathrm{V}$ \\
\hline Kogyoku & Japan & V \\
\hline Kurume 34 & Japan & $\mathrm{C}$ \\
\hline Kurume 103 & Japan & V \\
\hline Miyazaki & Japan & V \\
\hline Mo-ikko & Japan & V \\
\hline Morioka 16 & Japan & V \\
\hline Morioka 26 & Japan & $\mathrm{V}$ \\
\hline Morioka 30 & Japan & $\mathrm{V}$ \\
\hline Morioka 32 & Japan & V \\
\hline Morioka 33 & Japan & $\mathrm{V}$ \\
\hline Morioka 34 & Japan & V \\
\hline Natsuakari & Japan & V \\
\hline Nyoho & Japan & V \\
\hline Ohishi Shikinari & Japan & V \\
\hline Reiko & Japan & $\mathrm{V}$ \\
\hline Sachinoka & Japan & $\mathrm{C}$ \\
\hline Sagahonoka & Japan & $\mathrm{C}$ \\
\hline
\end{tabular}

(Continued on next page)

(Continued on next page) 
Table 1. (Continued) Country of origin and the detected chloroplast DNA haplotype of 75 accessions of Fragaria $\times$ ananassa and seven accessions of its wild relatives.

\begin{tabular}{llc}
\hline Accessions & Country & Haplotype \\
\hline Summer Candy & Japan & $\mathrm{C}$ \\
Summer Princess & Japan & $\mathrm{V}$ \\
Summerberry & Japan & $\mathrm{V}$ \\
Tochihitomi & Japan & $\mathrm{C}$ \\
Tochiotome & Japan & $\mathrm{C}$ \\
Toyonoka & Japan & $\mathrm{C}$ \\
Yachiyo & Japan & $\mathrm{V}$ \\
Wild relatives & & \\
F. virginiana & \\
F. virginiana & \\
F. chiloensis & & $\mathrm{V}$ \\
'PI551445' & & $\mathrm{V} 2$ \\
F. vesca EMC & & $\mathrm{C}$ \\
F. vesca UC1 & & \\
F. vesca UC5 & & Vesca \\
F. nilgerrensis & Vesca \\
\hline Germplasm & & Vesca \\
\hline
\end{tabular}

${ }^{\mathrm{z}}$ Germplasm conserved in the National Agricultural Research Center for Tohoku region, Morioka, Japan

${ }^{y}$ Seeds were purchased from the B\&T World Seeds, Paguignan, France, in 2002.

ploidy levels. Distinctive sequences for each species, including $F$. virginiana and $F$. chiloensis, were found in the trnL-trnF region, and $F$. ×ananassa showed the same sequence as $F$. virginiana. Although this analysis examined only one sample of $F$. Xananassa and therefore did not provide further information about the involvement of other wild species in the establishment of $F$. ×ananassa, sequence variation in cpDNA may allow us to infer the origin of each strawberry cultivar.

In this study, we investigated the mode of inheritance of cpDNA and then identified the maternal origin of $F$. ×ananassa. We discuss the accuracy of the reported pedigree of cultivars and the relationship between cpDNA haplotype and June yellows, a leaf variegation disorder in strawberry.

\section{Materials and Methods}

We collected fresh leaves from 75 accessions of $F$. xananassa and from a total of seven accessions from four related species, $F$. virginiana, $F$. chiloensis, $F$. vesca, and $F$. nilgerrensis, grown at the National Agricultural Research Center for Tohoku Region, one of Japan's official gene banks for strawberries (Table 1). Total DNA was extracted by using a modified PEG method (Rowland and Nguyen, 1993) with Plant DNAzol Reagent (Invitrogen, Carlsbad, CA), as described by Sugimoto et al. (2005). Two noncoding regions of cpDNA were selected for polymerase chain reaction (PCR) amplification, because previous studies revealed that these regions contain intraspecific polymorphisms (Potter et al., 2000; Honjo et al., unpublished data), specifically the spacer between $\operatorname{trn} L$ and $\operatorname{trnF}$ and the spacer between trnR and rrn5. The primers used are listed in Table 2. The PCR reaction mix contained $1 \times$ PCR buffer $[10 \mathrm{~mm}$ Tris $\cdot \mathrm{HCl}$ (pH 8.3), $50 \mathrm{~mm} \mathrm{KCl}, 100 \mu \mathrm{M}$ each dNTP, $0.02 \%$ Triton X-100, $0.01 \%$ gelatin], $1.5 \mathrm{~mm}$

Table 2. Chloroplast DNA primers used in the analysis of Fragaria $\times$ ananassa, annealing temperature, and references.

\begin{tabular}{|c|c|c|c|}
\hline Primer & Sequence $5^{\prime}-3^{\prime}$ & $\begin{array}{l}\text { Annealing } \\
\text { temp }\left({ }^{\circ} \mathrm{C}\right)\end{array}$ & References \\
\hline$\overline{\operatorname{trn} L(\mathrm{UAA})}$ & GGTTCAAGTCCCTCTATCCC & 50 & Taberlet et al. (1991) \\
\hline $\operatorname{trn} F(\mathrm{GAA})$ & ATTTGAACTGGTGACACGAG & & Taberlet et al. (1991) \\
\hline $\operatorname{trn} R(\mathrm{ACG})$ & CGACACCGTGGTTCGTAGC & 50 & Yoshimura et al. (unpublished data) \\
\hline $\operatorname{rrn} 5$ & TGGTGTCCCAGGCGTAGAG & & Yoshimura et al. (unpublished data) \\
\hline
\end{tabular}

$\mathrm{MgCl}_{2}, 0.9$ units Taq polymerase, $0.2 \mu \mathrm{M}$ of each primer, and $10 \mathrm{ng}$ template DNA in a total volume of $30 \mu \mathrm{L}$. Thermocycling conditions were as follows: $3 \mathrm{~min}$ at $94{ }^{\circ} \mathrm{C}$; 30 cycles of $30 \mathrm{~s}$ at $94{ }^{\circ} \mathrm{C}, 45 \mathrm{~s}$ at $50{ }^{\circ} \mathrm{C}$, and $45 \mathrm{~s}$ at $72{ }^{\circ} \mathrm{C}$; and a final extension step at $72{ }^{\circ} \mathrm{C}$ for $5 \mathrm{~min}$. The PCR was carried out in a GeneAmp PCR System Model 9700 (Applied Biosystems, Foster City, CA) or a PCR Thermal Cycler Dice (Takara, Tokyo, Japan). The PCR products were purified with a QIAquick PCR purification Kit (Qiagen $\mathrm{GmbH}$, Hilden, Germany). The DNA obtained was sequenced with an ABI PRISM 310 Genetic Analyzer (Applied Biosystems) using a BigDye Terminator Cycle Sequencing Ready Reaction Kit (Applied Biosystems). Sequencing data were aligned manually with CLUSTAL W (Thompson et al., 1994). Insertions/deletions (indels) were generally placed so as to increase the number of matching nucleotides in a sequence position. We determined cpDNA haplotypes from nucleotide substitutions and indels. To show the relatedness of haplotypes, we constructed a median-joining network (Bandelt et al., 1999) with epsilon value set to zero using the software Network 4.5.0.0 (http://www. fluxus-engineering.com).

To confirm the mode of inheritance of cpDNA in $F$. Xananassa, we performed controlled cross-pollination between cultivars possessing different haplotypes (Table 3 ). We examined the haplotype for one to five seedlings per cross.

\section{Results}

We found two haplotypes (V and V2) in $F$. virginiana that differed only in the number of tandem repeats of mononucleotides in the intergenic spacer between $\operatorname{trn} R$ and $r r n 5$ (Tables 1 and 4). Fragaria chiloensis, F. vesca, and $F$. nilgerrensis possessed the distinct haplotypes $C$, vesca, and nil, respectively. In $F$. Xananassa, we detected three haplotypes (V, C, and X). Haplotype X displayed the same sequence as haplotype $\mathrm{C}$ in the spacer between $\operatorname{trn} L$ and $\operatorname{trn} F$ and as haplotype $\mathrm{V}$ in the spacer between $\operatorname{trn} R$ and rrn5. The median-joining network analysis placed haplotype X between haplotypes V and $\mathrm{C}$ (Fig. 1). The nucleotide sequences of these haplotypes will appear in the DNA Data Bank of Japan under accession numbers AB514801 to AB514816.

We found haplotype $\mathrm{V}$ in 61 cultivars of $F$. ×ananassa originating from a diverse geographic range, namely, North America, Europe, and Japan. All North American cultivars except 'Columbia' possessed haplotype $\mathrm{V}$. We found haplotype $\mathrm{C}$ in 11
Table 3. Chloroplast DNA haplotype of seedlings obtained from controlled cross-pollination of cultivars of Fragaria $\times$ ananassa.

\begin{tabular}{lc}
\hline Parentage (female $\times$ male) & Haplotype \\
\hline Haplotype $\mathrm{C} \times$ haplotype $\mathrm{V}$ & \\
$\quad$ Sagahonoka $\times$ Natsuakari, No.1 & $\mathrm{C}$ \\
Sagahonoka $\times$ Natsuakari, No.2 & $\mathrm{C}$ \\
Sagahonoka $\times$ Natsuakari, No.3 & $\mathrm{C}$ \\
Sagahonoka $\times$ Natsuakari, No.4 & $\mathrm{C}$ \\
Sagahonoka $\times$ Natsuakari, No.5 & $\mathrm{C}$ \\
Sagahonoka $\times$ Selva, No.1 & $\mathrm{C}$ \\
Sagahonoka $\times$ Selva, No.2 & $\mathrm{C}$ \\
Haplotype V $\times$ haplotype C & \\
Natsuakari $\times$ Sagahonoka, No.1 & $\mathrm{V}$ \\
Natsuakari $\times$ Sagahonoka, No.2 & $\mathrm{V}$ \\
Natsuakari $\times$ Sagahonoka, No.3 & $\mathrm{V}$ \\
Selva $\times$ Sagahonoka & $\mathrm{V}$ \\
Haplotype V $\times$ haplotype X & \\
Morioka $32 \times$ Sagahonoka) & \\
$\times$ Cambridge Favourite & $\mathrm{V}$ \\
Haplotype X $\times$ haplotype V & \\
Cambridge Favourite $\times$ Aiberry & $\mathrm{X}$ \\
Cambridge Favourite $\times$ & $\mathrm{X}$ \\
$\quad$ Kitanokagayaki & \\
Cambridge Favourite $\mathrm{x}$ Morioka 32 & $\mathrm{X}$ \\
Haplotype X $\times$ haplotype C & \\
Cambridge Favourite $\times$ Sachinoka & $\mathrm{X}$ \\
\hline
\end{tabular}

Japanese cultivars and the American cultivar Columbia. We detected haplotype X in only two English cultivars, Cambridge Favourite and Merton Princess.

All seedlings obtained from controlled cross-pollination possessed the same haplotypes as their maternal parents (Table 3 ).

\section{Discussion}

The results of the controlled crosses (Table 3) indicate that the cpDNA of $F$. xananassa is maternally inherited, as it is in many angiosperms, including other Rosaceae genera such as Prunus (Bouhadida et al., 2007), Malus (Matsumoto et al., 1997), and Rubus (Moore, 1993).

Haplotypes $\mathrm{V}$ and $\mathrm{C}$ correspond to the haplotypes of $F$. virginiana and $F$. chiloensis, respectively (Table 1). Furthermore, the sequences of the trnL-trnF region of each haplotype also corresponded to the sequences of most of $F$. virginiana and $F$. chiloensis accessions analyzed by Potter et al. (2000), respectively. Six of the seven accessions of F. virginiana analyzed by Potter et al. (2000) corresponded to haplotype $\mathrm{V}$ in our study and one to haplotype C. Also, six of the seven accessions of $F$. chiloensis corresponded to haplotype $\mathrm{C}$ and one to haplotype V. Three of the seven accessions of the diploid species $F$. vesca also corresponded to haplotype V. Thus, $F$. virginiana predominantly possesses haplotype $\mathrm{V}$ and $F$. chiloensis haplotype C. Haplotype V can be regarded as more 
Table 4. Substitutions, indels and repeat variation in $\operatorname{trn} L-\operatorname{trn} F$ and $\operatorname{trn} R-r r n 5$ regions of chloroplast DNA in some Fragaria species.

\begin{tabular}{|c|c|c|c|c|c|c|c|c|c|}
\hline \multirow[b]{3}{*}{ Haplotype } & \multicolumn{9}{|c|}{ Gene region/sequence position } \\
\hline & \multicolumn{6}{|c|}{ trnL-trnF } & \multicolumn{3}{|c|}{ trnR-rrn5 } \\
\hline & $\overline{100}$ & 117 & 126 & $186-188$ & $266-272$ & 433 & $162-171$ & 173 & 180 \\
\hline$\overline{\mathrm{V}}$ & $\mathrm{C}$ & $\mathrm{T}$ & A & - & - & $\mathrm{T}$ & AAAAAAAAAA & G & G \\
\hline $\mathrm{V} 2$ & $\mathrm{C}$ & $\mathrm{T}$ & $\mathrm{A}$ & - & - & $\mathrm{T}$ & AAAAAAAAA & G & G \\
\hline $\mathrm{C}$ & $\mathrm{C}$ & $\mathrm{T}$ & A & - & - & $\mathrm{C}$ & AAAAAAAAAA & $\mathrm{T}$ & G \\
\hline $\mathrm{X}$ & $\mathrm{C}$ & $\mathrm{T}$ & A & - & - & $\mathrm{C}$ & AAAAAAAAAA & G & G \\
\hline Vesca & $\mathrm{C}$ & $\mathrm{T}$ & A & - & CATATCA & $\mathrm{T}$ & AAAAAAAAAA & G & G \\
\hline Nil & $\mathrm{T}$ & $\mathrm{C}$ & $\mathrm{C}$ & ATA & - & $\mathrm{T}$ & AAAAAAAAAA & $\mathrm{G}$ & $\mathrm{T}$ \\
\hline
\end{tabular}

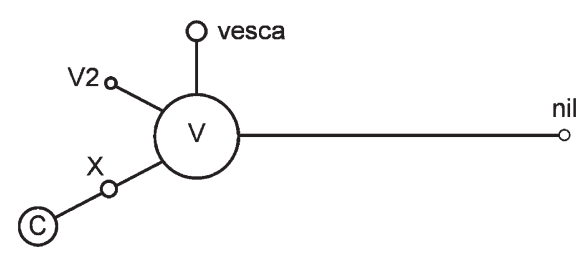

Fig. 1. Median-joining network of the chloroplast DNA haplotypes of Fragaria $\times$ ananassa (C, V, $\mathrm{X}), F$. virginiana $(\mathrm{V}, \mathrm{V} 2), F$. chiloensis $(\mathrm{C}), F$. vesca (vesca), and $F$. nilgerrensis (nil) based on the sequences of two noncoding regions. Each letter corresponds to a haplotype, and the size of the circle is proportional to the haplotype's frequency.

ancestral than haplotype $\mathrm{C}$ judging from the relationship with $F$. vesca. The accession that contained haplotype $\mathrm{C}$ despite being classified as $F$. virginiana was considered to be the result of introgression, and the accession that contained haplotype $\mathrm{V}$ despite being classified as $F$. chiloensis was inferred to be originated from a population that may have been established earlier in the evolution of the two species (Potter et al., 2000). Although haplotype X was not found in wild species, the median-joining network suggests that plants belonging to haplotype $\mathrm{X}$ could be classified as either $F$. virginiana or $F$. chiloensis (Fig. 1). The sequence of haplotype $\mathrm{X}$ appears to reflect an intermediate point in the process of differentiation between $F$. virginiana and $F$. chiloensis. These results confirm that $F$. Xananassa is an interspecific hybrid of $F$. virginiana and $F$. chiloensis (Darrow, 1966) and indicate that traditional cultivars of $F$. ×ananassa derive from at least three maternal lineages.

Haplotype V is widely distributed, and appears to be predominant in North America (Table 1). Dale and Sjulin (1990) reported that 134 cultivars released in North America between 1960 and 1987 were derived from, at most, 17 maternal founding clones. Of those inferred 17 lineages, three were identified their native clones from pedigree data. Our results support that pedigree: 'Columbia', which was recorded to be derived from $F$. chiloensis 'Reedsport', possessed haplotype $\mathrm{C}$, and 'Arking' and 'Cardinal', which were derived from $F$. virginiana 'The Native Iowa', possessed haplotype V. Although the other 14 founding clones were impossible to trace further on the basis of the pedigree data, our results suggest that nine of these 14 originated from $F$. virginiana, because either they or their progeny possessed haplotype $\mathrm{V}$ (Table 1). The nine are 'Missionary', 'Marshall', 'Hudson Bay' (ancestor of 'Sequoia' and 'Wiltguard'), 'Middlefield' (ancestor of 'Chandler', 'Douglas', 'Hecker', and 'Selva'), 'Chesapeake' (ancestor of 'Allstar' and 'Linn'), 'Aberdeen' (ancestor of 'Holiday' and 'Raritan'), 'Neunan' (ancestor of 'Pajaro' and 'Tyee'), 'Ettersburg 450' (ancestor of 'Honeoye' and 'Vibrant'), and 'Streamliner' (ancestor of 'Geneva'). It is apparent that there has been a strong founder effect in the spread of haplotype $\mathrm{V}$ in North America.

Of the Japanese cultivars analyzed in this study, 11 (28\%) possessed haplotype C (Table 1), indicating that cultivars with $F$. chiloensis maternal origin are more common in Japan than in North America. Strawberry ment of the cultivar Fukuba in 1899. We found that 'Fukuba' possesses haplotype C, which probably explains the relatively high frequency of haplotype $\mathrm{C}$ in Japanese cultivars, because its lineage has frequently been used for breeding in Japan.

We found haplotype $\mathrm{X}$ in only two cultivars, Cambridge Favourite and Merton Princess (Table 1). Both cultivars were bred in England, 'Cambridge Favourite' in 1947 from a cross between ('Etter seedling' $\times$ 'Avant Tout') $\times$ 'Blakemore' and 'Merton Princess' in 1956 to 1957 (Darrow, 1966). This suggests that presumably few individuals possessing haplotype $\mathrm{X}$ were collected and transferred to England and used for breeding.

Chloroplast DNA variation can be used to verify maternal parentage. 'Kurume 34 ' is a valuable accession because it is the source of several commercially important Japanese cultivars, including 'Toyonoka', 'Sachinoka', and 'Tochiotome' (presently the most commonly grown cultivar in Japan). 'Kurume 34' is long believed to have been bred from 'Yachiyo' $\times$ 'Donner' (Honda et al., 1976). However, we found that 'Kurume 34' and its descendants possess haplotype C, whereas both 'Yachiyo' and 'Donner' possess haplotype V (Table 1; Fig. 2). This suggests that some of the flagship cultivars in Japan are descended from different maternal origin from what has hitherto been reported.

Although the contribution of cytoplasmic genes to agronomically important traits of the strawberry is not well understood, several studies have implicated the cytoplasmic or chloroplast genome in June yellows (Hughes, 1989; Jeong et al., 1988; Rose, 1992), which is a progressive and deleterious chlorosis of breeding in Japan began with the establish-

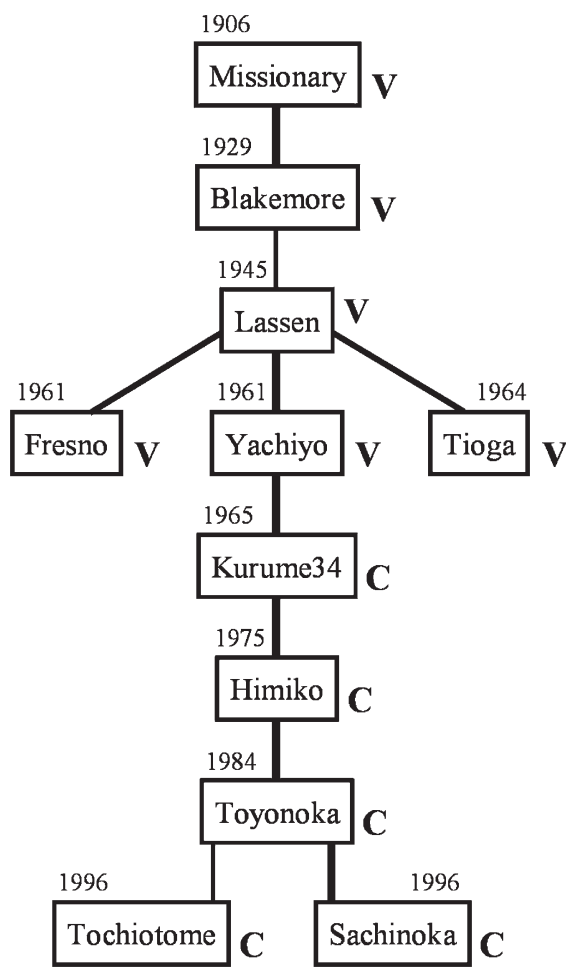

Fig. 2. Reported maternal pedigree of strawberry cultivars leading to Japanese flagship cultivars Tochiotome and Sachinoka. The numbers indicate the year released and the bold letters indicate the chloroplast DNA haplotype of the cultivars. Bold and thin lines connecting accessions indicate a relationship between mother and progeny and that between grandmother and grandchild, respectively.

strawberry leaves (Darrow, 1966; Jamieson and Sanford, 1996). Jeong et al. (1988) and Rose (1992) suggested that inheritance of shade-adapted chloroplasts from $F$. virginiana is one of the possible causes of June yellows. Our study included a number of cultivars in which June yellows has occurred (Hughes, 1989): 'Howard 17 (Premier)', 'Blakemore', 'Pajaro', 'Senga Sengana', 'Tyee', and 'Cambridge Favourite'. All but one possessed haplotype $\mathrm{V}$, which originates from $F$. virginiana. The exception, 'Cambridge Favourite', possessed haplotype X. In contrast, June yellows has so far not been reported from cultivars possessing haplotype $\mathrm{C}$ in Japan, although seedlings related to 'Howard 17 (Premier)' developed the condition, just as they do in North America and Europe (Hanaoka et al., 1964). These factors appear to support the arguments of Jeong et al. (1988) and Rose (1992). Also, Rose (1992) raised the possibility that June yellows is an example of hybrid variegation that arises after interspecific crosses in plants with biparental plastid inheritance, resulting in a nonharmonious interaction between the plastids of one parent and the hybrid genome after the "sorting out" of plastids that are compatible. However, we obtained no evidence of cpDNA inheritance from the male parent to progeny. Further analysis of the chloroplast and nuclear genes that play a major role in plastome-genome incompatibility (Yao and Cohen 2000) may 
lead to the identification of the mechanism underlying June yellows.

\section{Literature Cited}

Bandelt, H.J., P. Forster, and A. Rohl. 1999. Median-joining networks for inferring intraspecific phylogenies. Mol. Biol. Evol. 16:37-48.

Bouhadida, M., J.P. Martin, G. Eremin, J. Pinochet, M.M. Moreno, and Y. Gogorcena. 2007. Chloroplast DNA diversity in Prunus and its implications on genetic relationships. J. Amer. Soc. Hort. Sci. 132:670-679.

Dale, A. and T.M. Sjulin. 1990. Few cytoplasms contribute to North American strawberry cultivars. HortScience 25:1341-1342.

Darrow, G.M. 1966. The strawberry. History, breeding and physiology. Holt, Rinehart and Winston, New York, NY.

Hanaoka, T., T. Takai, S. Henmi, and T. Sato. 1964. Studies on the breeding of strawberries adapted to the northern part of Japan. I. On leaf variegation and the correlation of several characters to the yield. Bulletin of the horticultural research station (Min. Agric. For.), Series C. Morioka. 1:95-104 [in Japanese with English summary].

Hancock, J.F., P.W. Callow, A. Dale, J.J. Luby, C.E. Finn, S.C. Hokanson, and K.E. Hummer. 2001. From the Andes to the Rockies: Native strawberry collection and utilization. HortScience 36:221-225.
Honda, F., T. Amano, and T. Matsuda. 1976 Studies on the breeding of new strawberry variety 'Himiko'. Bulletin of the vegetable and ornamental crops research station, Series C. 2:114 [in Japanese with English summary].

Hughes, J.d'A. 1989. Strawberry June yellows-A review. Plant Pathol. 38:146-160.

Jamieson, A.R. and K.A. Sanford. 1996. Field performance of June yellows-affected clones of 'Blomidon' strawberry. HortScience 31: 848-850.

Jeong, B.-R., L.S. Daley, J. Postman, W.M. Proebsting, and F.J. Lawrence. 1988. Changes in chlorophyll-protein complexes associated with June yellows of strawberry. Photochem. Photobiol. 47:91-100.

Luby, J.J., J.F. Hancock, A. Dale, and S. Serce. 2008. Reconstructing Fragaria $\times$ ananassa utilizing wild $F$. virginiana and $F$. chiloensis: Inheritance of winter injury, photoperiod sensitivity, fruit size, female fertility and disease resistance in hybrid progenies. Euphytica 163:57-65.

Matsumoto, S., H. Wakita, and J. Soejima. 1997. Chloroplast DNA probes as an aid in the molecular classification of Malus species. Sci. Hort. 70:81-86.

Matsuoka, Y. 2005. Origin matters: Lessons from the search for the wild ancestor of maize. Breed. Sci. 55:383-390.

Moore, P.P. 1993. Chloroplast DNA diversity in raspberry. J. Amer. Soc. Hort. Sci. 118:371-376.
Potter, D., J.J. Luby, and R.E. Harrison. 2000. Phylogenetic relationships among species of Fragaria (Rosaceae) inferred from non-coding nuclear and chloroplast DNA sequences. Syst. Bot. 25:337-348.

Rose, J.B. 1992. A possible cause of strawberry June yellows-A degenerative, non-infectious condition. Plant Pathol. 41:379-383.

Rowland, L.J. and B. Nguyen. 1993. Use of PEG for purification of DNA from leaf tissue of woody plants. Biotechniques 14:735736.

Sugimoto, T., K. Tamaki, J. Matsumoto, Y. Yamamoto, K. Shiwaku, and K. Watanabe. 2005. Detection of RAPD markers linked to the everbearing gene in Japanese cultivated strawberry. Plant Breed. 124:498-501.

Taberlet, P., L. Gielly, G. Pautou, and J. Bouvet. 1991. Universal primers for amplification of three noncoding regions of chloroplast DNA. Plant Mol. Biol. 17:1105-1109.

Thompson, J.D., D.G. Higgins, and T.J. Gibson 1994. CLUSTAL W: Improving the sensitivity of progressive multiple sequence alignment through sequencing weighting, position-specific gap penalties and weight matrix choice Nucleic Acids Res. 22:4673-4680.

Yao, J.L. and D. Cohen. 2000. Multiple gene control of plastome-genome incompatibility and plastid DNA inheritance in interspecific hybrids of Zantedeschia. Theor. Appl. Genet. 101:400-406. 